\title{
Pelatihan Menyusun Laporan Laba-Rugi Usaha untuk Meningkatkan Kinerja Keuangan UMKM di Tanjung Piayu Kota Batam
}

\author{
Dian Lestari Siregar \\ Program Studi Akuntansi, Fakultas Ilmu Sosial dan Humaniora \\ Universitas Putera Batam \\ *e-mail : Dian.lestari@puterabatam.ac.id
}

\author{
Informasi Artikel \\ Diterima Redaksi: 29 Mei 2020 \\ Revisi Akhir: 30 Mei 2020 \\ Diterbitkan Online: 1 Juni 2020 \\ Kata Kunci: \\ Akuntansi, Laba-Rugi, Laporan Keuangan
}

\section{PENDAHULUAN}

Batam merupakan salah satu kota industri dimana aktifitas ekonominya sangat pesat jika dibandingkan dengan kota atau kabupaten lain di Provinsi Kepulauan Riau. Namun pertumbuhan ekonomi yang kurang baik pada beberapa tahun ini menjadikan perekonomian Batam melemah yang berdampak pada beberapa perusahaan yang tutup, sehingga dampaknya adalah pada pemutusan hubungan kerja (PHK) karyawan, hingga omset yang menurun akibat dari penurunan jumlah permintaan produksi dari konsumen (Tomi, 2017).

Sulitnya perekonomian yang dihadapi masyarakat menjadikan Usaha Mikro Kecil Menengah (UMKM) dilirik kembali. Pertumbuhan jumlah UMKM di Batam kian tahun semakin meningkat dan bertambah, namun jika ditelusuri secara finansial hanya beberapa UMKM yang mengalami perkembangan dalam hal kinerja keuangan. Lambatnya perkembangan tersebut tidak
Abstrak

Laporan Keuangan berfungsi sebagai alat untuk menganalisis kinerja keuangan yang dapat memberikan informasi tentang posisi keuangan, usaha, kinerja dan arus kas sehingga dapat dijadikan dasar membuat keputusan-keputusan ekonomi. Pengabdian yang dilakukan ini ditujukan kepada usaha odong-odong di Tanjung Piayu Kota Batam, dimana UKM tersebut belum memahami dan memiliki laporan keuangan. Usaha kecil ini mengalami kendala dalam penyusunan laporan keuangan dikarenakan kurangnya sumber daya manusia yang mereka miliki kemampuan dalam bidang akuntansi dan kurangnya alokasi waktu dalam menyusun laporan keuangan. Tujuan dari pengabdian ini yaitu mempersiapkan tenaga profesional akuntansi dalam Usaha kecil agar bersaing menghadapi tuntutan ekonomi, metode yang digunakan dalam pengabdian ini antara lain ceramah, tutorial dan diskusi, hasil Dari kegiatan yang telah dilaksanakan selama dua kali pertemuan telah mengubah persepsi dan pandangan pengusaha akan pentingnya pencatatan laporan keuangan

lepas dari ketidak sadaran pelaku UMKM terhadap pentingnya pengelolaan keuangan perusahaan, seperti dari segi penyusunan laporan laba-rugi usaha.

Aspek penting dalam menunjang majunya sebuah usaha adalah adanya pengelolaan keuangan yang baik (Faruq, 2018). Dalam menyusun laporan laba rugi disusun melalui akuntansi dimana manfaat yang bisa diperoleh oleh para pelaku usaha adalah untuk mengetahui perkembangan kinerja usahanya, memilah dan membedakan harta perusahaan dan harta pemilik, membuat dan menyusun anggaran yang tepat, dan pelaku usaha mengetahui aliran uang tunai selama periode tertentu. Dari beberapa manfaat tersebut seharusnya mampu menyadarkan pelaku usaha akan pentingnya akuntansi dalam kegiatan usaha mereka.

Sasaran dilaksanakan kegiatan pengabdian ini juga mengalami permasalahan yang serupa seperti kasus 
diatas. Dimana pemahaman pengusaha akan pentingnya menerapkan akuntansi dalam usahanya sangat kurang. Usaha yang akan diberikan pelatihan tersebut bergerak dalam usaha Odong-Odong atau permainan anakanak. Lokasinya berada di kecamatan Piayu, Kota Batam. Usaha ini masih tergolong usaha kecil yang belum terdaftar dalam Usaha Mikro Kecil Menengah (UMKM).

Kendalanya adalah modal dan infrastruktur belum mencukupi yang dapat mendorong usaha untuk berkembang dengan pesat hingga memperoleh pendapatan dan mencukupi prasyarat terdaftar dalam Usaha Mikro Kecil Menengah (UMKM). Dari survey awal yang telah dilakukan oleh tim, sulitnya perkembangan usaha Odong-odong ini juga dipengaruhi oleh ketidakpahaman pengelolaan keuangan usaha yang baik oleh pengusaha. Hal tersebut dilatarbelakangi oleh adanya anggapan bahwa akuntansi tersebut sulit dan dianggap tidak penting.

Pelaku usaha juga merasa bahwa usaha yang dijalankan sudah berjalan dengan normal walau sebenarnya usaha tersebut tidak mengalami perkembangan. Saat pelaku usaha ditanyakan soal laba yang diperoleh setiap periode, mereka tidak bisa menunjukkan dengan nominal angka melainkan dengan aset berwujud seperti tanah, rumah, atau kendaraan. Bahkan aset tersebut diperoleh tidak hanya lewat dana usahanya namun ditambah atau dicampurkan dengan harta pribadi. Aset tersebut terkadang juga bukan digunakan untuk perusahaan namun digunakan untuk kepentingan pribadi dan tidak terdapat pencatatan ataupun pemisahan antara aset pribadi dengan perusahaan. Hasilnya adalah perkembangan usaha dalam hal kinerja keuangan tidak bisa diketahui secara jelas.

Maka tujuan tim melaksakan kegiatan pengabdian berupa memberikan pelatihan mengelola keuangan dengan menyusun laporan laba-rugi guna meningkatkan kinerja usahanya. Dari adanya kegiatan ini diharapkan pelaku usaha dapat menyadari akan pentingnya akuntansi dalam sebuah usaha dan dapat mengetahui lebih pasti perkembangan usaha

\section{METODE}

Kegiatan pembinaan menyusun laporan keuangan sederhana ini dilaksanakan dan dibagi ke dalam dua tahapan. Pertemuan pertama dilaksanakan tanggal 12 Februari 2018 dimulai dari pukul 13.00 sampai 16.30 WIB. Kegiatan tersebut dimulai dengan pembukaan serta sambutan sebagai penyampaian rasa terimakasih yang disampaikan langsung oleh ketua pengabdi. Kemudian dilanjutkan oleh penyambutan dari pemilik usaha UKM yakni Ibu Desy, yang langsung dilanjutkan oleh penyampaian materi inti yang disampaikan oleh Dian Lestari Siregar, S.E., M.Si. topik yang disampaiakan adalah pembinaan penyajian laporan keuangan dan jenis-jenis laporan keuangan.

Pertemuan kedua kegiatan pembinaan dilaksanakan pada tanggal 19 Februari. Kegiatan dimulai pada siang hari pukul 13.30 sampai 17.00 WIB. Pertemuan ini melanjutkan kegiatan pertama. Dimana hal pertama yang dilakukan oleh tim adalah mereview kembali materi yang sudah pernah disampaikan kepada pemilik usaha yang bergerak di bidang UKM. Setelah dilakukan kaji ulang, barulah dilanjutkan pada materi lanjutan yakni membahas tentang bagaimana menyusun laporan keuangan sederhana dan menyusun laporan labarugiUntuk memperoleh manfaat dari pengabdian ini serta dapat diimplementasikan, maka metode yang ditawarkan dalam pengabdian ini adalah sebagai berikut:

1. Langkah 1 (metode ceramah):

Peserta diberikan motivasi dan pemahaman agar memahami gambaran umum akuntansi tentang laporan keuangan sehingga dapat mengaplikasikan cara pencatatan pembuatan laporan keuangan. Kegiatan ini dijalankan selama kurang lebih satu jam.

2. Langkah 2 (Metode Tutorial)

Peserta akan diberi Pembinaan dalam membuat laporan keuangan mulai dari komponen pemasukan, pengeluaran, serta beban, sehingga peserta pelatihan mengetahui serta memahami apa saja komponen dari laporan keuangan dan bagaimana cara membuatnya.

3. Langkah 2 (metode diskusi):

Peserta pelatihan diberikan kesempatan untuk mendiskusikan permasalahan yang berkaitan dengan cara pencatatan 
laporan keuangan usaha yang dihadapi oleh usaha. Langkah ketiga ini diadakan dalam sesi terakhir setelah ceramah.

\section{HASIL DAN PEMBAHASAN}

Konteks pelaksanaan pembinaan yang diadakan selama dua kali pertemuan pada tanggal 12 dan 19 Februari menyampaikan tentang perkenalan dan mengenal kembali apa itu akuntansi. Pengabdi merasa wajib untuk menyampaikan materi tersebut sebagai pembukaan untuk mengingatkan kembali pentingnya akuntansi yang harus diterapkan tidak hanya dalam kehidupan sehari-hari, namun juga dalam kegiatan bisnis dan usaha. Apakah itu usaha dan bisnis yang kecil ataupun usaha dan bisnis yang besar sekalipun.

Peserta pada saat itu mengakui tidak pernah menyusun laporan keuangan usahanya sama sekali. Usaha tersebut sudah berjalan aktif hampir tiga tahun, tapi pengusaha tidak pernah mencatat secara detail laba dan rugi usahanya. Pemilik usaha hanya menggunakan perkiraan dan perasaan. Sehingga saat tim pengabdi mengkonfirmasi berapa penghasilan perbulan, pengusaha hanya menjawab angka yang tidak pasti dan hanya mengira-ngira saja.

Maka disinilah peran penting tim pengabdi memberikan pemahaman akan bagaimana pentingnya pencatatan akuntansi tersebut, yang dimulai dari:

1. Menyampaiakan Pengertian akuntansi dan macam macam jenis laporan keuangan

2. Bentuk laporan arus kas masuk dan arus kas keluar

3. Pencatatan perubahan modal dan laporan laba rugi

4. Fungsi laporan keuangan

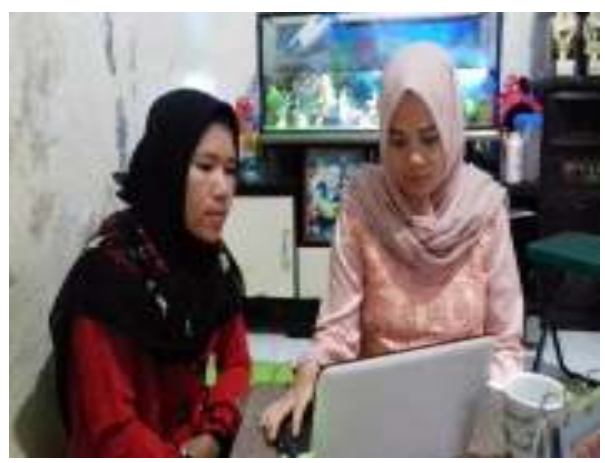

Gambar 1. Penyampaian Materi

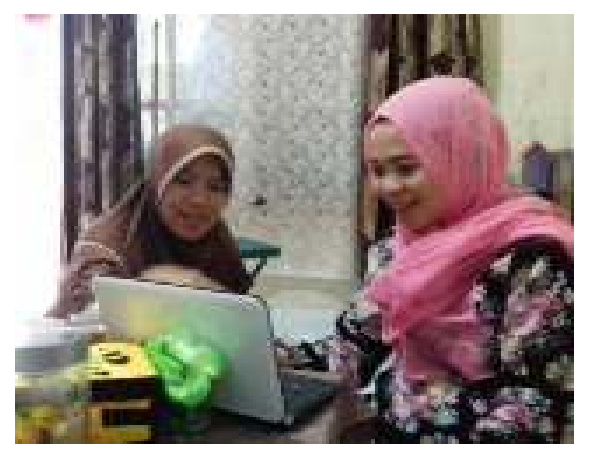

Gambar 2. Pelatihan Penyusunan Laporan Keuangan

Dari kegiatan yang telah dilaksanakan selama dua kali pertemuan telah mengubah persepsi dan pandangan pengusaha akan pentingnya pencatatan laporan keuangan. Pemilik usaha juga mulai menyadari manfaatnya, dan mulai memahami sedikit demi sedikit ilmu yang telah ditransfer oleh tim pengabdi. Tim pengabdi berharap kegiatan ini dapat terus berlanjut hingga pertemuan-pertemuan selanjutnya, begitupun dengan pemilik usaha, yang mengharapkan kegiatan ini dapat dilaksanakan secara rutin dan berkelanjutan. Harapannya, hasil akhir dari kegiatan ini, pemilik usaha bisa mengembangkan usahanya jauh lebih baik, yang dilengkapi oleh pelaporan pencatatan laporan keuangan yang rapih setiap periodenya. Sehingga membantu pengusaha mencari solusi akan permasalahan-permasalahan yang dihadapi hingga terus meningkatkan usaha dengan hasil laba yang terlah dicapai

\section{KESIMPULAN}

Kesimpulan yang dapat ditarik dari adanya kegiatan pembinaan yang berlangsung selama dua kali ini adalah:

1. Memacu dan meningkatkan keinginan pemilik usaha untuk memahami dan menerapkan pencatatan laporan keuangan dalam meningkatkan kegiatan usahanya

2. Pengembangan dan pembinaan pada para pedagang atau UMKM sebagai 
upaya untuk meningkatkan hasil usaha yang mereka peroleh

3. Kegiatan pembinaan ini sebagai kegiatan dalam meningkatkan produktivitas kerja dengan cara membina dan memonitoring kegiatan

\section{SARAN}

Kegiatan serupa dapat terus dilaksakana secara berkelanjutan dengan pembahasan materi yang lebih luas lagi, Dibutuhkannya dukungan tekhnologi seperti LCD guna mempermudah penyampaian materi, Diharapkan agar pengusaha lebih aktif dalam menggali ilmu pengetahuan dalam hal pencatatan laporan keuangan usaha baik dari lembaga-lembaga tertentu lainnya

\section{UCAPAN TERIMA KASIH}

Ucapan terimakasih penulis sampaikan kepada Universitas Putera Batam khususnya Lembaga Penelitian dan Pengabdian Masyarakat yang telah membantu kegiatan ini. Tidak lupa disampaikan kepada Desi selaku UMKM yang telah memberikan support dan membantu kegiatan pengabdian masyarakat ini.

\section{REFERENSI}

[1] Tomi, "Pertumbuhan ekonomi kepri menurun," BatamTimes.co, 2017.

[Online]. Available:

http://www.batamtimes.co.

[Accessed: 04-Feb-2018].

[2] I. Faruq, "Cara mengelola keuangan

bisnis dan usaha secara efektif,"

Centrausaha.com, 2018. [Online].

Available: https://centrausaha.com.

[Accessed: 02-Feb-2018]. 